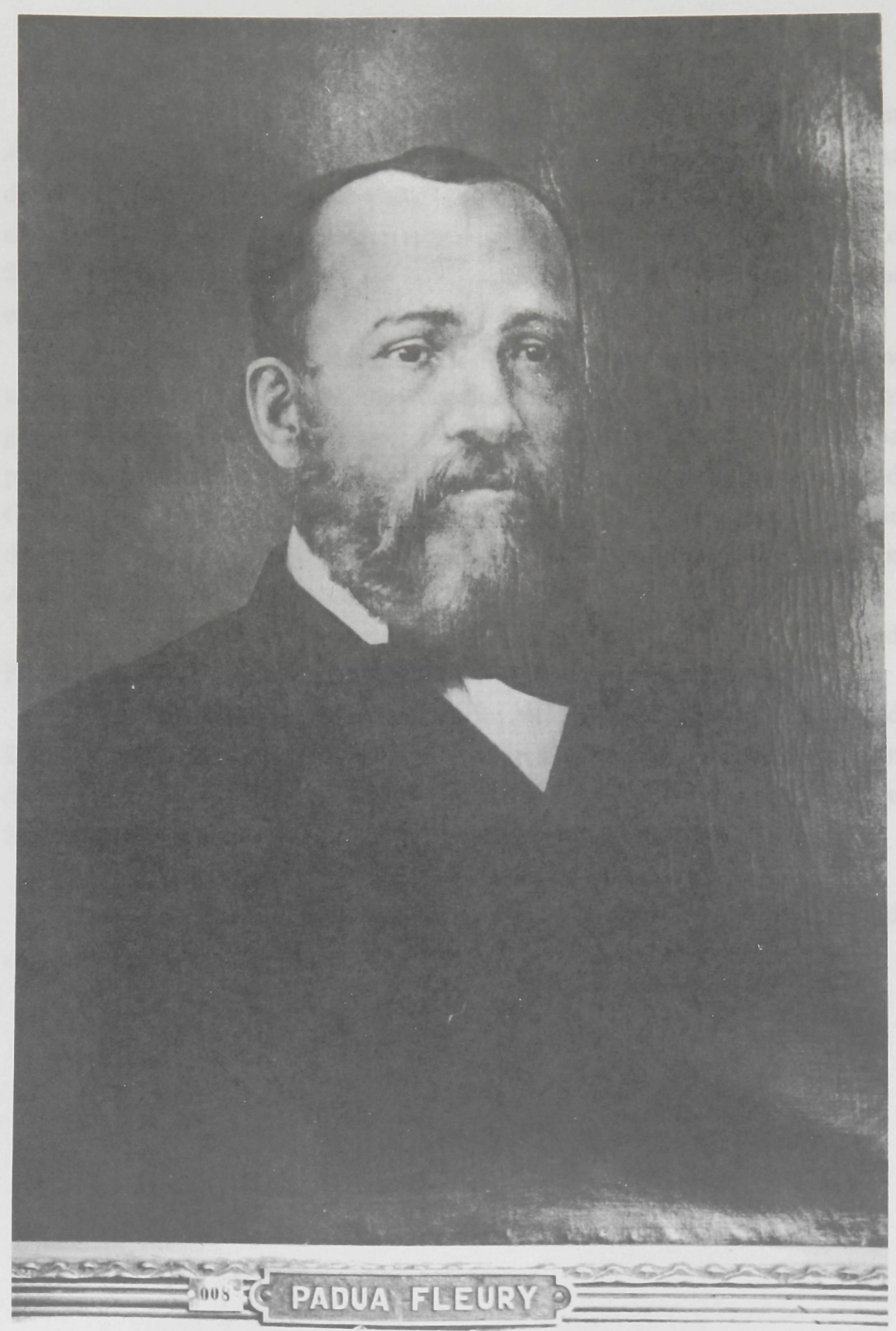





\section{Conselheiro Dr. ANDRÉ AUGUSTO DE PADUA FLEURY}

(1883-1890)

Natural de Cuiabá, província de Mato Grosso, filho do Tenente Antonio de Padua Fleury e de D. Augusta Rosa Gandel. Nasceu aos 18 de agosto de 1830. Tendo feito o curso do Colégio Pedro II, recebeu o grau de bacharel em ciências e letras em 1848 e, no ano seguinte, matriculou-se no Curso Jurídico de São Paulo. Bacharelou-se em 1853 e, logo, em 1854, foi nomeado juiz municipal em Goiás.

Voltando à Corte, exerceu ali a advocacia, ao mesmo tempo que servia na Secretaria de Estado dos Negócios da Justiça, na qual chegou a diretor geral. Comissionado pelo governo, foi à Europa estudar os diversos sistemas penitenciários, apresentando a respeito notável estudo. Em 1860, foi membro da Comissão Inspetora da Casa de Correção. De 1878 a 1879, presidiu as províncias de Santa Catarina e do Ceará. Representou, na décima oitava legislatura, na Assembléia Legislativa, a província de Goiás.

Ocupou, no gabinete de 4 de julho, organizado pelo Visconde de Paranaguá, a pasta da Agricultura, Comércio e Obras Públicas.

Por decreto de 16 de janeiro de 1883, foi nomeado diretor da Faculdade de Direito de São Paulo, à qual prestou ótimos serviços. Foi sob sua direção que o prédio da faculdade sofreu a reforma que lhe deu o aspecto que hoje tem, dotando-a de novo mobiliário, melhorando a biblioteca, etc.

Em 1885 foi eleito deputado geral por Mato Grosso.

Aposentou-se por decreto de 9 de agosto de 1890. Foi condecorado com o título de conselheiro. 